\title{
Is there enough leisure time? Leisure studies, work-life balance, the realm of necessity and the realm of freedom
}

\author{
A.J. Veal \\ University of Technology Sydney, Australia
}

Published as: Veal, A.J. (2020). Is there enough leisure time? Leisure studies, work-life balance, the realm of necessity and the realm of freedom. World Leisure Journal. 62(2), 89113. DOI: $10.1080 / 16078055.2019 .1667423$.

\begin{abstract}
In economically advanced countries in recent years, working hours of many full-time employees have been static or increasing and there has been talk of people suffering from a 'time squeeze'. Researchers in the field of leisure studies have not featured strongly in debates surrounding this issue, having generally shown little interest in the work-leisure time relationships since the 1970 s, being preoccupied instead with leisure activity, meaning and experience. However, calls for reduced working hours have been forthcoming from other sources, such as feminists, economists, critical theorists and environmentalists. In this paper it is proposed that leisure studies scholars re-engage with this issue using the Marxian concepts of the 'realm of necessity' and the 'realm of freedom' as an analytical device.
\end{abstract}

Key words: working hours; leisure time; work-life balance; realm of necessity; realm of freedom

\section{Introduction}

The field of leisure studies emerged in the post-World War II period, following half a century in which, despite depression and war, economically developed countries had seen the standard full-time working week fall from about 60 hours to 40, the introduction of paid annual holidays and yet substantial growth in workers' real incomes. It was widely expected that these trends would continue and there was even talk of an emerging 'leisure society' (Veal, 2011). However, it was later discovered, beginning with the research of Hunnicutt $(1980,1988)$ and then Schor $(1991)$, that the downward trend in working hours was no longer in train and, in the USA at least, may have gone into reverse. With the increasing involvement of women in the paid workforce, evidence subsequently emerged that many in Western societies were becoming 'time-squeezed' (Hochschild, 1989, 1997; Schulte, 2014). Since the relationship between work and leisure was a major initial focus of the field of leisure studies (e.g., Smigel, 1963; Anderson, 1967), leisure studies scholars might have been expected to have much to say about this changing environment and its causes and consequences. However, in addition to Hunnicutt and Schor, only a few other leisure scholars, such as Robinson and Godbey (1997), Roberts (2007) and Zuzanek (2009), have shown an interest in the quantum of paid work and non-paid-work time. A number of others in the 1970s and 1980s pursued the work-leisure relationship in terms of the qualitative influence of types of paid work on types of leisure activity, and these are reviewed below. The bulk of the leisure studies community, however, lost this thread of concern and moved on to other 'projects' (Mommaas, 1997; Bramham, 2006; Aitchison, 2012). The aim in this paper is to trace the story of part of this thread and link it with current social concerns.

The next section considers Marx's distinction between the 'the realm of necessity' and the 'realm of freedom' as a conceptual device to frame this investigation. This is followed by a 
chronological review of the treatment of the work-leisure relationship in the research literature since the 1930s. The final sections draw attention to a range of calls for reduced working hours from a variety of sources and concludes that this should also be a concern of the field of leisure studies.

\section{The realm of necessity and the realm of freedom}

Karl Marx divided time and activity into two categories, related to 'the realm of necessity' and the 'realm of freedom' respectively.

- The realm of necessity involved both paid-work time, devoted to earning an income in the economic sector to pay for the necessities of life, and non-paid-work time which was devoted to the process of 'reproduction of labour power' (Marx, 1867/1957: 268). The non-paid-work component was time which the worker needed for 'the growth, the development, and healthy maintenance of the body ... for consumption of fresh air and sunshine ... meal time ... and healthy sleep for the collection, renewal, and refreshment of the vital powers' (p. 269).

- The realm of freedom comprised additional non-paid-work time for the purposes of 'education, for intellectual development, for the fulfilment of social functions, for friendly intercourse, for the free play of physical and mental forces' (p. 268). However, under the conditions of industrial capitalism of the mid-nineteenth century, the long hours of work demanded of the typical industrial worker to secure a living wage, and the time required for the 'renewal and refreshment of the vital powers', resulted in realm-of-freedom time being reduced to zero. By contrast, in the communist society it was envisaged that paidwork time would be reduced and realm-of-freedom time would become available to workers. The gaining of access to this time, denied by the capitalist system, was therefore seen as one of the key motivations for workers to seek its overthrow ${ }^{\mathrm{i}}$.

The reduction in working hours which has taken place in Western capitalist countries over the last 150 or so years did not feature in Marx's view of the future development of capitalism. The question nevertheless arises as to whether the expansion in the amount of non-paid-work time has been sufficient to adequately reproduce labour power and therefore for workers to progress, at least quantitatively, to the realm of freedom.

For the purposes of this paper, accepting the proposition of the usefulness of the realm-ofnecessity/realm-of-freedom distinction does not imply anything about the nature or uses of realm-of-freedom time ${ }^{\mathrm{ii}}$. Competing views on this issue have preoccupied various leisure scholars and others down the years, but it is not the focus in this paper. If, even under present conditions, the non-paid-work portion of realm-of-necessity time is inadequate for the reproduction of labour power, concerns about the nature of realm-of-freedom activities would seem to be somewhat premature. Furthermore, the answer to the question posed in the title of the paper would be that there is not enough leisure time. Arguably, the failure to address the issue of realm-of-necessity activity has left leisure studies ill-equipped to contribute to key contemporary debates on work/non-work time.

Marx's work/non-work scenarios under capitalism and socialism/communism can be represented diagrammatically as shown in Figure 1. This depicts the distribution of time between work and rest/recuperation over the course of a day, with time shown on the horizontal axis and the worker's level of fatigue on the vertical axis. Part (a) depicts conditions under capitalism in which all the time not spent in paid work is required for rest, recuperation and related activity required to reduce the worker's level of fatigue to zero and 
renew and refresh the 'vital powers', ready for a new day's work. Part (b) shows the conditions under imagined socialism/communism, in which hours of work are fewer, thus reducing the level of fatigue and the amount of time required for rest and recuperation, and releasing additional leisure time which is in the realm of freedom.

a. Male working day under capitalism

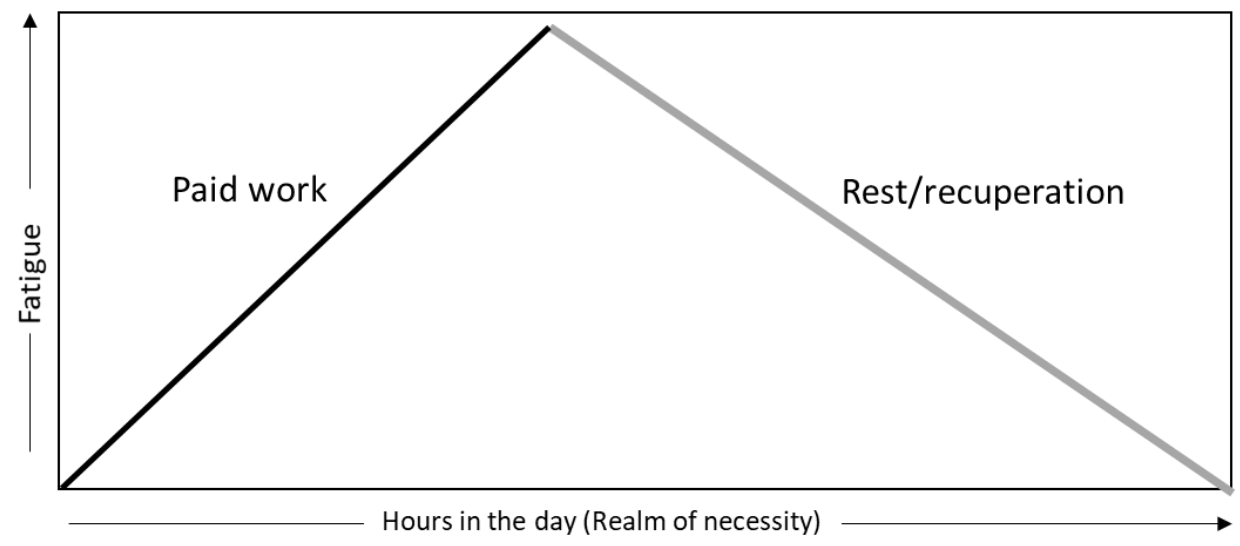

b. Male working day under socialism/communism

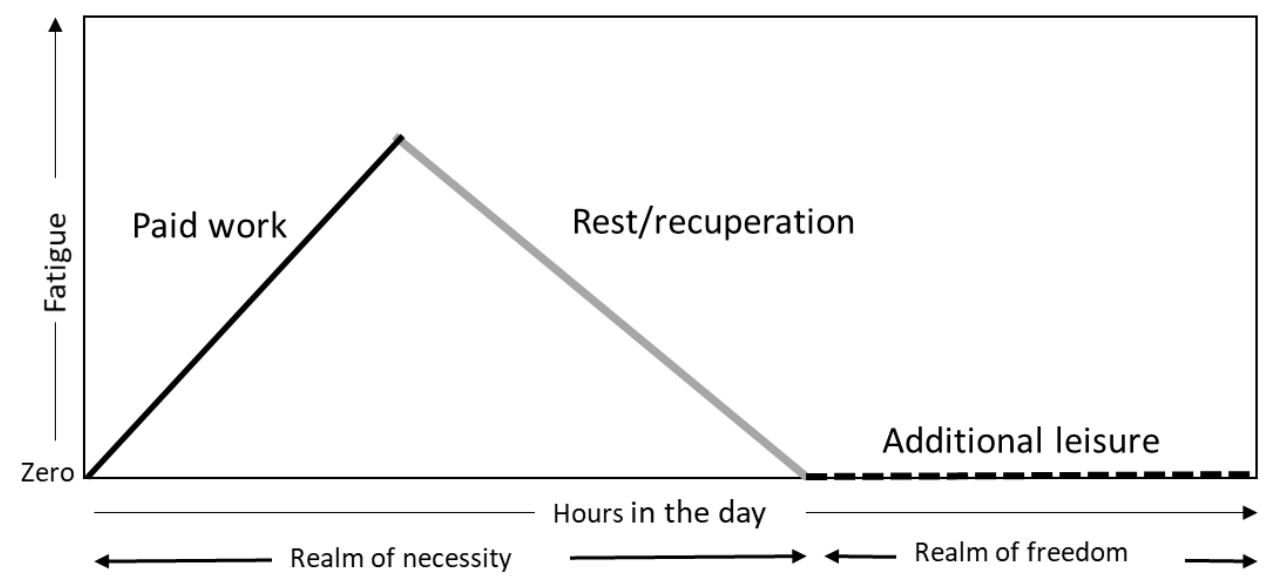

Figure 1 Representation of Marxian scenarios of daily time-use patterns Source: Author's visual interpretation of Marx (1867/1957: 268-9).

Figure 1 is, of course, a very simplified representation of a single day. In fact, days are ordered in weeks, and workers do not necessarily fully recover from fatigue on a daily basis; there is a residual which accumulates over the working week, from which the worker seeks to recover at the weekend. Furthermore, unpaid domestic work is also part of the realm of necessity and it also results in fatigue. These developments are represented by the elaboration of Figure 1a presented in Figure 2.

This brings into the picture the evolving distinctive traditional and contemporary roles of men and women. In Marx's analysis this was not spelled out in detail; domestic work in the nineteenth century was overwhelmingly done by women, while paid workers, who were the main focus of Marx's analysis, were mainly male. In current conditions, women make up a significant proportion of the paid labour force. They also continue to undertake the bulk of unpaid domestic work/childcare, although there is somewhat more sharing between the sexes than in previous generations. While Figure 2 can be seen as multi-purpose, in detailed empirical research separate diagrams could be developed for men and women and/or a combined version could be developed for the household. 


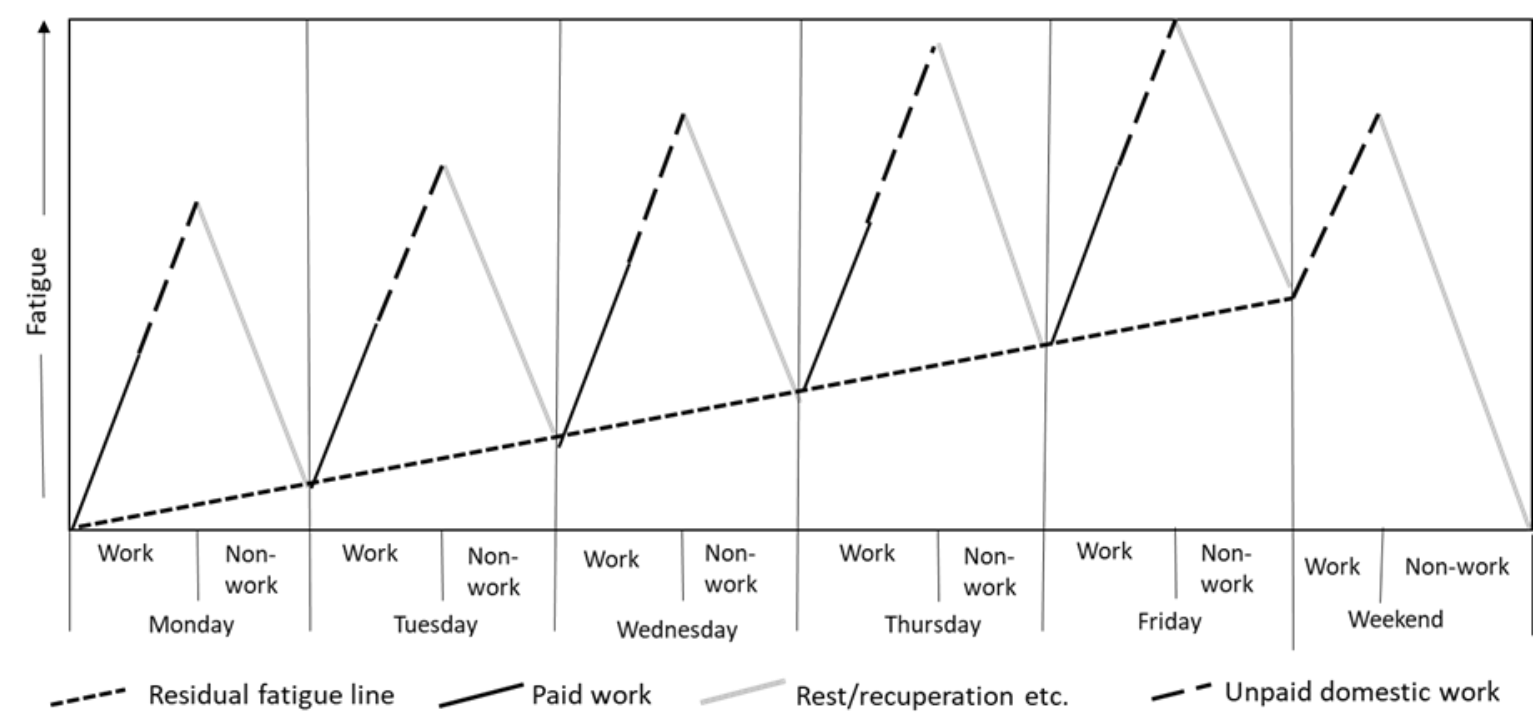

Figure 2 Weekly time-use pattern including unpaid domestic work

In Figure 2, the relative sizes, degree of fragmentation and sequencing of the paid work and unpaid domestic work categories will of course vary, depending particularly on the individual's gender, economic status and domestic responsibilities. It also depends on the type of work, since physical and/or mental fatigue varies between types of job, and among individuals doing similar jobs, and may be affected by the extent to which workers find their jobs interesting or boring or fulfilling or meaningless. While rest is shown as one continuous process of recovery from fatigue, it could also involve periods of strenuous leisure activity which themselves create fatigue. Rest/recuperation time can therefore be seen as related to recovery not just from the effects of paid and unpaid work but from all of the activities and cares of the day and the week.

The analysis could also be extended to cover a whole year, including holidays, and the whole lifetime, including retirement. The idea that accumulated effects of the work experience, in the form of such phenomena as 'burn-out' and chronic health conditions, might extend over periods longer than a year is clearly an issue worth examination, but it is not pursued in this paper.

Since 'labour power' in capitalist countries has been maintained and increased over the years, it might be thought that the time available for realm-of-necessity activities must have been adequate. However, history suggests otherwise. The typical mid-nineteenth-century industrial working week of about 70 hours left some 98 hours a week for other activities, which employers, and presumably governments, of the time deemed adequate. However, the late nineteenth and early twentieth centuries saw intense campaigns for reduced working hours, based particularly on worker fatigue, suggesting that the period of 98 hours was not considered adequate for full recovery (Cross, 1989: 113-5). This was based not only on concern for the welfare of workers but also on the grounds that fatigued workers were less productive (Chapman, 1909: 356). It might be thought that worker fatigue is no longer an issue, but a recent review of conditions in US workplaces declares: 'Fatigue is a significant problem in modern society, largely because of high workplace demands, long duty periods, disrupted circadian rhythms, social and societal demands, and insufficient sleep' (Caldwell, Caldwell, Thompson and Lieberman, 2019: 272; see also: Dembe, 2009; Lenneis and Pfister, 2017). 
Historically, claims were also made that reduced working hours were necessary for: women in the paid workforce for 'creating and maintaining a wholesome family life'; children, also in the workforce, for the sake of their health and education; and all workers for the 'discharge of ordinary duties of citizenship and domestic life' (Cross, 1989: 117). These concerns could be interpreted in terms of social welfare, but also in functional terms, that is as a component of the broad process of effectively 'reproducing labour power'.

A question arises regarding not just the quantum of time required for rest and recuperation but also the whole range of non-paid-work activities involved and their associated time requirements. Marx's brief list of activities, cited above, included sleep and eating meals as well as leisure activities. Furthermore, while his list of realm-of-freedom activities included fulfilment of social functions and education, these could equally be seen as realm-of-necessity activities, in the form of, respectively, maintenance of family/social relationships and development of skills for work purposes. Thus the non-paid-work component of realm-ofnecessity activities can be said to include unpaid domestic work and all the personal, domestic, social and leisure activities which constitute day-to-day living; hence, the reference is to rest/recuperation etc. in Figure 2.

Leisure scholars and others have advanced numerous approaches to analysing time-use patterns but most do not take account of the full range of day-to-day, realm-of-necessity, activities (see review in Veal, 2019a: 37-51). One schema, which reflects this complexity and the above discussion, is presented in Figure 3. This 'leisure1-4' classification system includes not only 'rest and recuperation' (leisure1) and 'diversion/entertainment' (leisure2) but also family-related leisure (leisure3), which can include activities with immediate family/ household members and extended family and close friends. Categories 1-3 are part of the realm of necessity; they tend to overlap a great deal, both among themselves and with other realm-of-necessity activities, such as community involvement and domestic work/care. Leisure 4 takes place in realm-of-freedom time, if it exists at all. Individuals who claim to be time-squeezed may be short of time for any or all of the realm-of-necessity activities and are likely to have little if any time for realm-of-freedom activity. There is a tendency for much of the leisure studies literature to treat leisure time as an undifferentiated whole, often seeming to assume that it consists entirely of leisure 4, while omitting prior consideration of leisure 1-3.

Figure 3 Individuals' time allocation

\begin{tabular}{|c|c|c|c|c|c|c|c|c|c|}
\hline \multicolumn{9}{|c|}{ Realm of necessity } & \multirow[t]{2}{*}{ Realm of freedom } \\
\hline & bour & & & & Reproduct & n of labour power & & & \\
\hline $\begin{array}{l}\text { Paid } \\
\text { work }\end{array}$ & $\begin{array}{l}\text { Grey } \\
\text { work* }\end{array}$ & Sleep & $\begin{array}{l}\text { Body } \\
\text { care }\end{array}$ & $\begin{array}{l}\text { Comm- } \\
\text { unity }\end{array}$ & $\begin{array}{l}\text { Domestic } \\
\text { work \& care }\end{array}$ & $\begin{array}{l}\text { Leisure 1 } \\
\text { Rest, recuperation }\end{array}$ & \begin{tabular}{|l|} 
Leisure 2 \\
Entertainment
\end{tabular} & $\begin{array}{l}\text { Leisure3 } \\
\text { Family }\end{array}$ & $\begin{array}{l}\text { Leisure4 } \\
\text { Other }\end{array}$ \\
\hline
\end{tabular}

Source: Adapted 'leisure1-4' system (Veal, 2019a: 32, 39). * = journey to work + unpaid job-related activity.

This framework is objectively analytical but it also provides a framework to support discussion of a variety of explicit and implicit normative issues which arise in this paper. Thus, for example, the paper starts with identification of a contemporary problem of 'time squeeze' which suggests that time available to complete the daily round of realm-of-necessity activity is inadequate and this is judged to be unjust and/or deleterious to the well-being of those affected. Furthermore, the state of freedom implied by the realm of freedom would be widely held to be a desirable state and its systemic denial to individuals, groups or classes would be judged negatively. 


\section{The work-leisure relationship in leisure studies: 1930s to the present}

This part of the paper presents a chronological examination of leisure studies discourses to determine the extent to which they have referred, directly or indirectly, to: the quantum of non-paid-work time and its adequacy; the idea of the binary division of time into realm-ofnecessity and realm-of-freedom categories; and the idea that realm-of-necessity activity involves rest and recuperation from work-related fatigue as well family activity and a range of other leisure and non-leisure activities. In each case, the leisure-related normative/ theoretical framework of the contribution is also identified.

\section{The 1930s and the 'new leisure'}

Reductions in the standard working week from its nineteenth century peaks were well underway in the 1930s, when commentators began to refer to the arrival of the 'new leisure' (Neumeyer and Neumeyer, 1936; 1949: 15). The leisure was 'new' in both the quantitative sense of newly release time resulting from reduced working hours and in the qualitative sense of the emergence of new types of mass leisure activity, such as radio-listening, movie-going and the professionalization of spectator sport. Both gave rise to intensification of longstanding normative concerns of members of the commentariat regarding the leisure activities of the working class, embodied in the saying that: 'the devil makes work for idle hands'. Susan Currell (2005: 3) notes that the 1930s saw: 'thousands of books and articles published in the mass media about a new 'problem of leisure'. Some of these were from academics, but it is not possible to review them in detail here ${ }^{\mathrm{iii}}$. American educationist Jay Nash is selected as an exemplar because his discussion is particularly detailed and, while he first entered the debate in the 1930s (Nash, 1932), his contributions continued into the 1950s (Nash, 1953/ 1960) and became part of the field of leisure studies then emerging in the USA.

Nash divided time into vocation, or paid-work-time, and two categories of non-paid-work time: re-creation, corresponding approximately to realm-of-necessity leisure activity, and avocation, to realm-of-freedom activity. He observed:

With the reduction of working hours, less time will be needed for re-creation, used purely in the sense of recuperation and restoration. This throws a large part of time into the third part, which is new, and for which we have no symbol in the English language, save what might be called avocation, a time for creation, or a time for pure choice, or ... time for creative arts' (Nash, 1932: 8).

Thus, for Nash, the question regarding the adequacy of the quantum of time for rest and recuperation was seemingly answered, albeit with no explicit reference to evidence or quantification. His main concern was, then: 'What will man do with this machine-formed time?' (p. 8). Here he also had a ready answer: 'There are glaring indications on all sides that, given leisure, man will turn into a listener, a watcher. He will attempt to utilize this new leisure, which should be devoted to creative arts, in body recuperation. He will rationalize that he needs rest ... far beyond his actual requirement' (Nash, 1932: 8-9). This tendency was given the quasi-medical label spectatoritis, which was used as the title for Nash's book.

In his post-war publication, Nash (1955/1960) presented a typology of leisure activity, reproduced in Figure 4. The left-hand side of the diagram indicates a scale, running from subzero and zero to four and then to 'infinity'. The normative basis for the scale is the 'progress and development of the individual and the group'. The body of the diagram and the righthand descriptions define types of leisure activity in a passive-active/creative hierarchy, which can be seen as Nash's explication of the idea of 'progress and development'. Level 1 
activities correspond approximately to realm-of-necessity activities and the higher levels to realm-of-freedom activities.

The functional dimension of the typology was, however, down-played by Nash. While he discussed the idea of re-creation relieving physical and mental fatigue and stress caused by work elsewhere in the book (pp. 48-53), this was not mentioned in the diagram itself, and only in passing and grudgingly in the accompanying commentary: 'On the first level, corresponding to the base of the triangle, where most people seem content to remain, is passive participation, called spectatoritis. Sometimes being a spectator has its value; for example if a person can be sufficiently entertained to forget his fatigue' (Nash, 1953/1960: 93). Note, the fatigue would be forgotten, not overcome. Thus, while a certain amount of spectating/passivity was deemed acceptable to recover from fatigue, it was viewed as subsidiary to the idea that the increasingly passive American worker was failing to rise to the challenge of using the 'new' leisure time for active/creative purposes. This perceived problem was the focus of the bulk of Nash's commentary.

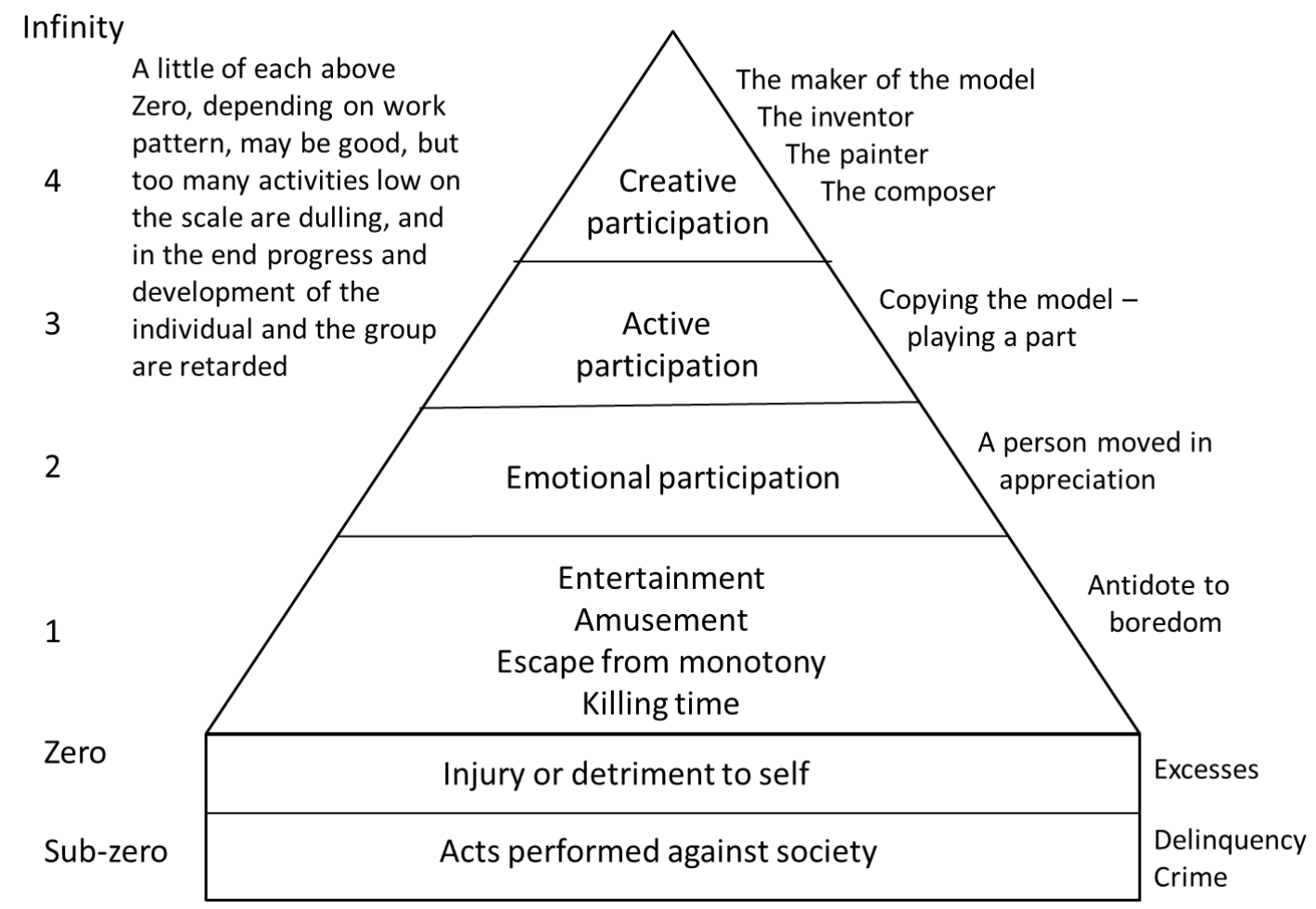

Figure 4. Nash's normative hierarchy of leisure activity

Source: Nash (1953/1960: 89)

In a chapter titled 'Man must belong', Nash states: 'there are at least two significant ways in which we can acquire a sense of belonging. One is through work and the other through creative recreation' (p. 105). At no point in the chapter is there discussion of the sense of belonging to be found in the family and its associated leisure and non-leisure activities.

While Nash noted with some regret the increasing levels of mostly commercial provision for passive leisure (pp. 28-32) and the failure of political leaders in the United States to provide moral leadership regarding alternatives (p. 45), he did not analyse the forces shaping the quantitative and qualitative divide between lower and higher level activities. The appropriate choice of 'new leisure' activity was seen as, ultimately, an individual matter (pp. 37ff). 


\section{The 1950s and 1960s}

The 1950s and 1960s saw the emergence of a number of recognised leisure scholars, pioneers of the field. Here we examine the contributions of: David Riesman (USA); a number of industrial sociologists featured in a collection edited by Erwin Smigel (USA); Max Kaplan (USA); and Joffre Dumazedier (France).

David Riesman, director of the short-lived Centre for the Study of Leisure at the University of Chicago, made a distinction between the manual worker and the professional or business person. The former, enjoying recently reduced working hours, 'leaves the plant with a good deal of energy left, which carries him through his leisure hours' (Riesman, 1954: 135). By contrast, the professional and business person was 'apt to leave his work with a good many tensions created by his reactions to interpersonal situations, and as a result his leisure "needs" may have to be satisfied before he can rise above the levels of needs - before he can rise from the level of re-creation to the level of creation. While he may nominally have a short workweek ... he has not got much time which is not filled with stress' (p. 135). The stress was also related to the demands of what later came to be referred to as 'helicopter parenting' and the development of new types of lifestyle 'devoted to the arts of consumption and leisure, where these arts are pursued with such a dogged determination that leisureliness as a quality of life is largely absent' (p. 137). Furthermore, seeking to adapt and fit into the new social and cultural milieu involving music, painting, literature, sociability and conversation, sport and changing styles of vacation, they were 'paying a high price in emotional outlay, particularly in anxiety' (p. 141). These impressionistic observations on the distinctive experience of manual and non-manual workers in regard to work, fatigue and lifestyle were not pursued further.

A number of contributions to a collection of papers by industrial sociologists published under the title Work and Leisure; A Contemporary Social Problem (Smigel, 1963) were relevant to the themes of this paper. They provided the starting point of some of the later empirical work of leisure researchers. Regarding the quantum of leisure time, Berger (1963: 27) observed, but with no reference to specific evidence, that reduced working hours meant that, "practically all of us have some "free time" beyond the minimum needed to restore or refresh the body for its economic tasks'. One possible indicator of the changing relationship between work and leisure was Dubin's (1963: 60) concept of 'central life interest'. He found that only 24 per cent of the manual workers he studied 'could be labelled job-oriented in their life interests'. Furthermore, while this finding was generally interpreted as indicating that leisure was the central life interest, in fact Dubin stated that, 'Nine out of ten of those studied clearly indicate that their preferred informal human associations and contacts were found in the community, among friends, and in the family'. Orzack (1963), however, found that among professional workers most indicated that 'work and the workplace' were central life interests, reflecting the distinction made by Reisman.

Kaplan (1960), in his seminal sociological analysis, Leisure in America, observed that the 'new leisure' had facilitated activity which was 'more than recuperation from work' (p. 297). However, while he reviewed available historical data on trends in working hours, he did not identify the point at which recuperation was complete and the new leisure time began. Reflecting the early labour movement's call for 'eight hours work, eight hours sleep and eight hours for what we will' (Rosenzweig, 1983), he observed, referring to male full-time workers: 'we have as much time during the day away from work as we have in work' (Kaplan, 1960: 3). This was also noted by others (e.g., Marcuse, 1962: vii; Riesman, 1964: 
186; Molitor, 2000), including Dumazedier (1971: 193; 1989: 144) who labelled it a historical inversion. However, none of these authors offered any theoretical explanation of the significance of this 'inversion' point.

Kaplan's widely cited definition of leisure comprised seven primarily experiential elements: antithesis to work; pleasure; minimum of social role obligations; perceived freedom; cultural relatedness; and playfulness (p. 24). Resting was not included as one of these elements. However, it was part of the separate definition of recreation, which functioned as: 'renewal or preparation for the continuance of routine and necessary work' (p. 19). Thus, this realmof-necessity component of non-paid-work time was excluded from the definition of leisure. A note of ambivalence, or inconsistency, was, however, struck when he stated: 'If the concept of leisure is equated with re-creation, it has no value in itself except as a supplement to work' (p. 24). This suggested that recreation could be viewed part of leisure if it was treated as instrumental. The third definitional element, minimum of social role obligation, is of interest since the main social roles involved were family-related and the issue of obligation was discussed, although the significance of the minimum qualification is not clear (p. 23). Nevertheless, realm-of-necessity activity seemed to have been included.

Regarding the content of leisure activity, Kaplan implicitly adopted a normatively hierarchical framework similar to that of Nash, but less explicit. His examination of a range of statistical information regarding the changing nature of leisure in America gave rise to concerns exemplified in the following observation: 'On the side of Light we could speak of the 1000 community orchestras or the 5000 community theatres; yet Darkness swells in our tears for the large audience to spectator sports' (p. 296). Kaplan was not concerned with the realm-of-necessity/recreation activities in his hierarchy, but with higher level leisure activity where, reflecting Nash, he asserted: 'creativity, broadly conceived, remains the paramount issue' (p. 296). This, despite the fact that creativity was not mentioned in his seven-element definition. The new leisure, he believed, could become 'a potential source of the deepest values' and could provide 'a variety of activity for creative expression' (p. 297). He recognised that this was a significant challenge to America (p. 300) and, like Nash, looked to the country's political leadership to set the appropriate social goals, but then asserted that these could be defined 'only as each of us individually, and all of us collectively, sets out a position of values or assumptions' (p. 303).

Similar issues were being addressed on the other side of the Atlantic in France. Industrial sociologist Georges Friedman (1945/1955, 1956/1966) initiated discussion with his observation that, while industrial work was physically less burdensome, it was becoming increasingly monotonous and alienating, but he was pessimistic about the extent to which workers could be relieved or compensated by reform of working conditions or increased leisure time activity. The first European sociologist to be identified with leisure, Joffre Dumazedier, built on this work with empirical sociological research on the work and leisure patterns of French workers. In Toward a Society of Leisure, Dumazedier (1962/1967) made no reference to Nash's work but did refer to Marx's view that the only leisure-time available to the worker in the nineteenth century had been the brief respite allowed for the 'reproduction of the labour force' (p. 11). Like Nash and Kaplan, he concluded that the twentieth century reduction in working hours had changed this situation.

Dumazedier's analytical approach was based, like Kaplan's, on a widely cited definition of leisure. It was functional rather than experiential, having three functions: (1) rest/relaxation; (2) entertainment/diversion; and (3) personal development (Dumazedier, 1962/1967: 14). 
Function (1) involved 'recovery from fatigue' and repair of 'physical and nervous damage wrought by the tension of the daily pressures ... particularly of the job' (pp. 14-15). While admitting that the need for physical effort on the job had 'largely disappeared' (p.15), he argued that the 'work of production in the industrial plant of today, more fragmentized and mechanized, and geared to a greater speed than in the nineteenth century, is also far more exhausting to the nerves of workers, so that they feel all the more a deep-seated need for rest and escape from the job' (p. 7). Function (2) was seen as particularly associated with 'escape from the job' and so was seen as part of the recuperation process.

The first two functions can therefore be considered as corresponding to realm-of-necessity activity. However, Dumazedier classified activities involving any sort of social or domestic obligation as semi-leisure, which was then sidelined from being considered as part of leisure itself (pp. 18-19). As a result, the idea of a range of domestic and personal leisure activities being viewed as part of the realm-of-necessity was not considered. This, despite the fact that, in Dumazedier's own survey of unskilled workers, $47 \%$ indicated that it was family activities that gave them the 'maximum satisfaction', compared with $25 \%$ leisure activities and $24 \%$ work (p. 87) $)^{\mathrm{iv}}$.

As with Nash and Kaplan, Dumazedier did not offer evidence to indicate that increased leisure time of the 1950s was adequate for recovery from the effects of work. He simply assumed that the French worker was ready to move on to function (3) activity. This was seen as a new order of activity, 'distinct from the job of production, distinct from social obligation, ... and constituting a revolutionary element within our social culture' (p. 11). His overall functional/definitional approach might have suggested a less normative stance towards this new leisure activity than Nash and Kaplan, but this was not the case. While, like Kaplan, he examined evidence on recent trends in workers' leisure behaviour (pp. 20-31), he stated: 'What is terrifying about leisure in our mechanised age is that it is liable to develop and maintain a generalized passivity' (p. 221). To counter this observed tendency, he proposed the establishment of a cultural council for France, to be concerned with 'mass leisure-time cultural development', to be a bulwark against both 'totalitarian propaganda', as seen in the Soviet Union, and 'free-enterprise incoherence', as offered by the USA (pp. 248-9).

Riesman, Kaplan and Dumazedier expressed ideas differently but, like Nash, each recognised to varying extents the conceptual distinction between the realm-of-necessity role of leisure (recreation in the case of Kaplan, semi-leisure in the case of Dumazedier) as well as the possibility of it being part of the realm of freedom. In the case of Kaplan and Dumazedier attention was, however, focussed primarily on their own cultural philosophy regarding suitable activities for the realm-of-freedom leisure activity, concluding that the modern worker was not responding adequately to the challenge. Riesman's key contribution was to suggest that the changing work-leisure experience might differ between manual and nonmanual workers.

Interestingly, other social researchers at the time were making arguably clearer observations about the adequacy of non-paid-work time than the leisure specialists. For example, the authors of the renowned British Affluent Worker studies noted that, 'after finishing work and carrying out their various familial obligations, our affluent workers and their wives wanted only to 'take it easy' and 'relax' before the daily round began again' (Goldthorpe et al., 1969: 102). In the USA, Herbert Gans (1968: 114) observed, on the basis of his research in Levittown, that 'actual time available for leisure behaviour is still fairly limited; ... by the time the children are put to bed, household maintenance activities are completed, and the 
grass is cut', few people 'have much energy for activities other than television, informal reading, socializing, and just relaxing'.

Before leaving the 1960s, we should note that neo-Marxist theorists have addressed the implications of reduced working hours under capitalism. An example from the 1960s was Herbert Marcuse (1964: 5) whose perspective on the additional time released from paid labour was that it was being spent on consumption activity. However, this was manipulated by advertising and other measures employed by capitalist producers, and was consequently meeting not real needs but 'false needs', so the realm of freedom was being denied. This theme is picked up again in later decades.

\section{The 1970s}

By the 1970s, when the field of leisure studies was more firmly established, the 'new leisure' was no longer new. Some of the changes in work/leisure time anticipated in earlier decades had been in place for some years. The question as to whether or not workers had passed into the realm of freedom had still not been subjected to empirical examination, but leisure scholars of this era did not seem to be interested in addressing it. That leisure time had increased and was continuing to do so was a backdrop to discussion, rather than itself the focus of inquiry. Furthermore, the distinction between realm-of-necessity and realm-offreedom leisure was not generally acknowledged: leisure was treated as an undifferentiated whole.

Kenneth Roberts (1970) recorded the transition to this perspective. He noted that, while 'Marx regarded the leisure offered to the worker under capitalism as a means whereby the labour force could be enabled to reproduce and rejuvenate itself', recent research on the work-leisure relationship had focussed on leisure as an 'opportunity to compensate for the frustrations and monotony that work in modern industry involves', and on the ways in which leisure was 'based upon values and interests generated at work' (pp. 23-24). He was critical of these approaches on the grounds that, in his view, research should be moving away from the idea of leisure being dependent on work to focus more on its role as a cultural phenomenon in its own right.

Roberts' view also marked a clear shift away from the normative considerations which had been so prominent in the work of the earlier authors. He asserted:

The job of sociology is not to judge the desirability of the leisure activities that are prevalent in a society, nor to advise people on how they should best use their leisure time. ...The discipline of sociology is value-free; its principal job is to describe and explain how people in particular social situations use their leisure, and this contribution ... can be made most effectively if the literature of sociology is kept as free from value judgements as is humanly possible. (Roberts, 1970: 9)

Roberts did not, however, avoid the normative altogether, since he aimed to debunk the normative statements of others, whose focus had moved from the 'new leisure' to 'popular/ mass leisure'. He dismissed critiques of the latter as merely a case of élite groups in society criticising the tastes of non-élite groups (Roberts, 1970: 104). By implication, therefore, he was opposed to the hierarchical view of leisure activities espoused by the likes of Nash, Kaplan and Dumazedier discussed above. In a later volume he provided a more detailed critique of 'mass society theory' and observed that the public had not been 'lured from the playing fields by an epidemic of spectatoritis' (Roberts, 1978: 58). Furthermore, he argued 
that contemporary leisure was not adequately explained by either 'mass society theory' or 'class domination theory' (i.e., neo-Marxism). He favoured 'socio-cultural pluralism' (acceptance of the market system), which involved a 'variety of taste publics that possess contrasting interests generated by their different circumstances' (p. 86). Compared with the implicit normative frameworks of earlier writers, Roberts' stance did appear to have been less subjectively based, in that it was explicitly argued in relation to alternative frameworks and against a background of a body of empirical data. However, critics who supported class domination/neo-Marxist theory could point to his lack of concern with the macro-processes by which 'taste publics' and their 'different circumstance' were formed and the implications of this for class and inequality (Clarke and Critcher, 1985: 43).

The other major UK-based leisure sociologist of the time was Stanley Parker, whose work exemplified the strand of research which Roberts had highlighted and critiqued. Like Roberts, Parker ostensibly eschewed any normative stance, which he saw as the domain of philosophy and religion. These disciplines were concerned with 'the quality and values of the good life', but sociology, by contrast, was 'concerned with relationships' (Parker, 1971: 13). The relationships Parker (1965) explored were between people's occupations and their leisure behaviour patterns. Based partly on the existing research literature and partly on interviews with samples of individuals from a number of occupations, he developed a three-fold typology of work-leisure relationships: extension or spillover (work and leisure activities are similar and often connected); opposition (leisure activities contrast with work activity); and neutrality or complementarity (leisure different from work but not affected by it) (Parker, 1971: 99). While it was 'not claimed that certain occupations and certain types of workleisure relationship always go together', a list of 'typical occupations' for each relationship was nevertheless provided (p. 107).

In an apparent attempt to derive some sort of broader theory from his individual-level findings, Parker resolved the three types of relationship into two 'schools of thought', namely: holism (= extension) and segmentalism (=opposition or complementarity) (p. 109). These could apply to individuals or society as a whole. Parker noted that, in regard to the desirability of the two approaches at the society level, his own survey evidence was 'inconclusive' but he stated: 'With holism and segmentalism, ... it is not so much a matter of weighing up evidence as of accepting or rejecting a philosophy of life' (p. 99). This, despite the earlier comment about being engaged in sociology and not philosophy. In the final chapter of his book Parker sought to analyse public policy for leisure using the segmentalist and holist dyad, with the latter clearly favoured. Thus he laid out a 'holist' pathway to 'the good life'.

Three specific observations on Parker's work should be made. The first concerns the continuity - or lack of it - with Dumazedier's thinking. In discussing 'kinds of leisure and their meaning today', Parker made use of Dumazedier's three-function definition of leisure (pp. 57-8), and later sought to draw a parallel between these functions and his own three-fold typology. Thus extension was associated with personal development; opposition with recuperation; and complementarity with entertainment (Parker, 1971: 108-9). The two lists are, however, incompatible, since Parker's relationships refer to an individual's predominant pattern of behaviour, whereas Dumazedier's functions apply to everyone at varying times and to varying extents. Parker clearly did not recognise this incompatibility, but did seem to be aware of some difficulty when he stated that, for example, someone with an extension pattern might sometimes feel 'the need for recuperation or for entertainment' (p. 109). 
Second, it has to be said that Parker's two-dimensional, mechanical work-leisure relationship typology is a very narrow basis upon which to build his propositions concerning the role of 'holist' philosophy in the 'good life'. In a publication of which Parker seems to have been unaware, Dumazedier (1974: 108-25) reported on extensive empirical analysis of workleisure relationships, concluding that 'dichotomous over-simplifying theories' of work-leisure relationships (such as Parker's) were 'already outdated' and 'the positive or negative influence of work on leisure is no more a source of problems than that of other factors which also condition leisure: family life, education, and socio-spiritual and socio-political commitments'. Roberts (1978: 113) endorsed this view, while others later made similar points - for example, Moorhouse (1998: 24) suggested the need to 'consider whether broader material and cultural factors might not be producing certain attitudes to both work and leisure', and Clarke and Critcher (1985: 21) suggested that, in Parker's model, the family was 'a missing link between work and leisure'.

The third observation is that, since Parker's work appeared at a time when leisure studies was developing rapidly, it was subject to a considerable amount of comment and critique. He was able to take account of some of this in a revised version of his book (Parker, 1983: 94-6), where he referred to six critical authors, although he omitted reference to Dumazedier's critique, noted above, or to Roberts' endorsement of it. He defended his main thesis, but modestly concluded: 'We are still some way from being able to make confident and reasonably reliable statements about the complex web of different dimensions of the workleisure relationship' (p. 97).

American psychologist John Neulinger (1974: 15-22) developed a six-fold typology of leisure and work activity based on the extent to which participation was intrinsically or extrinsically motivated. Leisure activity which was extrinsically motivated was characterised by satisfaction coming 'not from the activity itself but from its consequences'. These included 'recreation', which was seen as part of leisure, not separated from it. Examples of instrumental recreation included engaging in 'athletics because one wants to be in good health', or playing a game 'to overcome fatigue'. Thus realm-of-necessity concepts maintaining health, overcoming fatigue - were included within the scope of leisure. However, Neulinger's main interest was in intrinsically motivated leisure activity, so the extrinsic form of motivation and its implications were not explored further. There was no reference to family leisure, although 'household chores' were curiously counted as leisure if the person had 'the freedom of not doing them' (p. 20) or if they were 'enjoyable and do not need to be done' (Neulinger, 1981: 19). Neulinger's normative stance was evident in his condemnation of the materialism/consumerism promoted by the market system. He called for a 'revolution of consumers' with the slogan, 'Consumers of the world, unite!' (p. 218).

American sociologist John Kelly, in contributions to the debate on the definition of leisure, developed two paradigms, each consisting of a four-fold time/activity typology. The first was based on two framing dimensions: the level of discretion or freedom of choice in the decision to participate in leisure activity and the relationship with work (Kelly, 1972). The activity category which involved little or no discretion and was work-related was labelled 'recuperation or preparation'. It comprised relaxation, recuperation and escape from work, with television-watching specifically mentioned as an example. However, it was deemed not to be leisure since it was seen as incompatible with a key feature of leisure, namely freedom of choice. The typology was entirely conceptual, unsupported by empirical evidence, but when such evidence was later brought to bear, it resulted in substantially modified typology (Kelly, 1978). This was based on a different pair of framing dimensions: perceived freedom 
(high or low) and meaning (intrinsic or social). All four resultant activity categories were now deemed to be leisure, with one - intrinsically motivated/low freedom - labelled as 'compensatory and recuperative'. Furthermore, quantitative survey data indicated that this instrumental form of leisure activity was as common as leisure activity chosen for its own sake. So, under the guise of instrumentality, realm-of-necessity activity was restored as a feature of leisure and even subjected to empirical testing. The typology was not, however, picked up by other leisure scholars and was not pursued in Kelly's own later writings.

As noted above, the interest of industrial sociologists and psychologists in work-relationships was demonstrated by the early 1960s publication of Work and Leisure (Smigel, 1963). That interest continued, as evidenced by three reviews of the plethora of research on the topic published in the 1970s by: Kabanoff (1980); Near, Rice and Hunt (1980); and Staines (1980). A common feature of these review was the increasing complexity of the empirical research on work-leisure relationships. However, the typologies offered remained descriptive or, at best, correlational. All three reviews therefore argued that causal explanation and theory were generally lacking. While the earlier researchers had been guided by normative hierarchies of leisure activity linked to some philosophical conception of the 'good life', industrial sociologists were guided by the health or well-being, and effectiveness, of the worker. There was also some recognition that the 'non-work' parts of the worker's life included both leisure and family dimensions.

Neo-Marxist arguments concerning the use of time gained from reduced working hours was continued in the 1970s by French theorist Jean Baudrillard (1970/1998), although his observations did not appear in English until the 1990s. Without referring directly to Marx, he downplayed the functional significance of realm-of-necessity leisure activity required for the reproduction of labour power, stating: 'Rest, relaxation, escape and distraction are, perhaps, 'needs': but they do not in themselves define the specific exigency of leisure, which is the consumption of time' (p. 154). In his analysis Baudrillard reflected Marcuse's argument noted above, but mostly adopted Veblen's ideas of emulative conspicuous consumption and conspicuous leisure time as the mechanism by which free time was co-opted into serving the market system. As such, it was not deemed to be 'free'.

\section{The 1980s-1990s}

At the beginning of the paper, it was noted that Hunnicutt $(1980,1988)$ and Schor $(1991)$ alerted the leisure studies community to the post-war halt in the trend of falling working hours. As a leisure historian, Hunnicutt was content to document the historical origins of the change, resulting from government commitments to economic growth and full employment and workers' continually expanding appetite for the material rewards of paid work and prosperity. Schor's perspective, which was unorthodox for an economist, was that American workers, with weakened union representation, had unwillingly become overworked due to employer power to impose longer hours, almost a throw-back to nineteenth century conditions (see also Basso, 1998/2003). Workers then became accustomed to life on the 'work and spend' treadmill. However, spending money is not necessarily correlated with related spending of time, so just how leisure time was spent remained under-explored. As with the 1960s scholars, neither Hunnicutt or Schor distinguished between realm-of-necessity and realm-of-freedom activity. While Hunnicutt (1988: 21) referred to worker fatigue and recuperation in historical terms and Schor (1991: 65) mentioned it in passing, neither discussed it as a significant feature of the contemporary work-leisure relationship. 
Leisure studies of the 1980s was characterised by a significant introduction of critical, neoMarxist and feminist perspectives, typically accompanied by thorough-going critiques of existing functional/reformist and 'male-stream' research. Canadian sociologist Ed Andrew (1981) drew on the Weberian concept of the 'iron cage' of industrial, technological rationality to frame his somewhat neglected analysis of work and leisure under capitalism. He noted the inconsistency of available research on the extent to which work was or was not a 'central life interest' for workers, concluding that it was, for most people, 'not their work or their leisure but their home life' that was their central life interest (p. 177). However, making reference to the concepts of the realms of necessity and freedom, he declared that the family 'enlarges the realm of necessity and diminishes leisure time' (p. 178). He observed that it was a common, but mistaken, assumption in the sociology of leisure that the 'technical imperatives' of the iron cage pertained only to 'the realm of necessary production', whereas they also applied to 'the realm of freedom or leisure' (p. 181). Leisure, he argued, could not be freed by the cultural development or education of the workers, but only by dismantling the iron cage of the system of production by means of syndicalism - that is, workers taking control from below (pp. 182-3).

Like Andrew, Chris Rojek (1985) referenced the concepts of the realm of necessity and freedom. He noted that, in the context of the former, workers' leisure time under capitalism was limited to that required to: '(a) replenish their energies, (b) ensure the reproduction of the working class, and (c) provide an integrated market for capitalist production' (p. 42).

However, he offered no further discussion of item (a). The other two items were discussed entirely in terms of consumption as a market process, thus reflecting the perspectives of Marcuse and Baudrillard noted above. Under capitalism, any increased free time resulting from reduced working hours was absorbed into the realm-of-necessity activity of consumption and any possibility of realm-of-freedom activity was denied by this process.

The most well-known neo-Marxist perspective was presented in The Devil Makes Work: Leisure in Capitalist Britain by John Clarke and Chas Critcher (1985). While offering a thoroughgoing critique of mainstream leisure studies and a class-based alternative, Clarke and Critcher praised Parker's focus on the importance of work, and for maintaining that, for many, work remained 'a fundamentally damaging experience from which leisure can offer only limited recuperation'v. They then observed that it was not Parker's fault that work had 'come to be eliminated and hived off from leisure analysis' (p. 20). Their own discussion of the work-leisure relationship was, however, surprisingly sparse. A passing comment on the non-paid-work component of realm-of-necessity time appeared in a brief discussion of time 'at home', in which the 'private work of reproduction' took place, but it was not discussed further (pp. 97-8). The closing 'epilogue' of The Devil Makes Work outlined a political programme for leisure for the socialist movement in Britain, which also implied a research framework. While asserting that 'the problem of leisure' was 'also the problem of work', the perspective was broader than the concentration on work-leisure relationships. The starting point, it was argued, should be 'people's daily lives', which were 'not motivated by political abstractions but by the concerns which secure and mark out a more intimate framework of home and family, friends and relatives' (p. 233). Rather than campaigning for the right to work, it would be 'more socialist to reduce the time we all have to labour, releasing time and energy to explore other kinds of activity' (p. 234). Ultimately, therefore, what was at stake was, 'the politics of time' which was 'the invisible resource that structures many of the conflicts and inequalities of leisure'. It was time which was 'inequitably distributed between workers and non-workers, young and old and, especially, between men and women (Clarke 
and Critcher, 1985: 239). While making no explicit reference to the realm-of-necessity/realmof-freedom distinction, it begins to address related issues.

Feminist contributions to the study of leisure also made their appearance from the 1980s, notably in the work of Susan McIntosh (1981), Rosemary Deem (1986) and Eileen Green, Sandra Hebron and Diana Woodward (1990) in the UK. The main messages of this research were that women's experience of leisure was substantially different to that of men, upon whom most leisure research and theory had hitherto been based. The experience of leisure also varied among women, according to whether they were in part-time or full-time paid employment or were full-time carers, and whether they were parents. For most, leisure was significantly shaped by domestic/child-care responsibilities. Furthermore, leisure time and activity opportunities were constrained by limitations imposed by numerous public and private practices and assumptions of a patriarchal society. The result was that, compared with men, women had less time and less freedom of choice in leisure activity. One of the features of this research was the qualitative, ethnographic-style investigation of how women actually spent their time. It therefore offered the possibility of exploring the sorts of patterns illustrated in Figures 1-3 above, and this was to some extent achieved. It certainly appeared that women - particularly those with dependent children - were substantially preoccupied with realm-of-necessity activities. While leisure was present, it was characterised by fragmentation and constant responsibility for the care of others, so that individual 'freedom' was elusive. Recuperation was identified by the women studied by Green et al. (1990: 6) who indicated that a central feature of their leisure time was relaxation, presented as 'fundamentally a recuperative activity, a way of physically or mentally recharging one's batteries ... [and] rest and recovery from the demands of everyday life'. However, the adequacy of the availability of free time tended to be judged not in absolute terms, but in comparison with that of men. This implied that the solution to the inequity was for men to give up free time to take on a larger share of domestic work - something which has happened only slowly, if at all, in the intervening years. The question being explored in this paper is: even if such duties were to be equitably shared, would the combined realm-of-necessity time available to the typical two-parent household be adequate to complete all the paid and domestic work activity involved and leave both parents with sufficient leisure time to fully recuperate, let alone engage in realm-of-freedom activity?

At the end of the 1980s, Moorhouse (1989) offered a wide-ranging critical appraisal of leisure research. Parker's work was merely a 'typology of possibilities' which had yet to be turned into 'hypotheses capable of being tested' (p.23). Equally critical of feminist and neoMarxist contributions, he argued that the field might be advanced by using broader concepts from 'general social theory', such as lifestyle (p. 31) (see Veal, 2013).

The work-leisure relationship subsequently all but disappeared from leisure studies discourses. In discussing research on the work-leisure relationship, Roberts (1999: 57) observed that, by the end of the 1990s, this 'entire genre of research' had 'become almost extinct'.

\section{Beyond leisure studies: twenty-first century calls for reduced working hours}

While the leisure studies community has recently been comparatively mute on the workleisure relationship and the question of working hours, the twenty-first century has seen calls for reduced working hours from a range of non-leisure studies sources, including: feminists; 
environmentalists; economists; critical theorists; and social activists. Examples of these and their varying rationales are summarised below.

A number of feminist writers have called for reductions in working hours for all. In her critical Marxist-feminist book, The Problem of Work, Kathi Weeks (2011: 152) observes that feminism has tended to 'focus on the struggle for more and better work' for women, neglecting the possibility of 'struggling also for less work'. She proposes a 'post-work politics', in which full-time paid working hours are reduced for all and are seen as subservient to the process of 'getting a life' (p. 211). In Work Time: Conflict, Control and Change, Cynthia Negrey (2012) notes that, while work time has traditionally been addressed as an issue of public concern, it has also been a site of 'private troubles' which are assumed to be solved in the family/household unit. She argues that these two realms should be brought into closer alignment through a 'new political economy of work time' (p. 175), observing:

Long work hours and school routines mean we value market activity over almost everything else in life. A new, shorter, full-time work norm permits us to claim a larger sphere of non-market activity ... In redistributing our values from market to non-market activities, it is necessary to redistribute work time - good paid work from men to women, unpaid work from women to men, and overwork to the unemployed. ... Such restructuring of market work necessitates deconstructing the ideal worker norm. (Negrey, 2012: 191-92)

In Decolonizing Time, political scientist Nichole Marie Shippen (2014: 9) argues that the 'fight for time' is a political struggle rather than a labour struggle, citing the precedent of nineteenth century campaigns for legislation to limit the working hours of children and women. For today, she asserts: 'The fight for the reduced workday remains central to the struggle for autonomy, but transforming the political-economic conditions so as to decrease the overall reliance on the market for all goods and services is just as necessary for developing a politics of time today' (Shippen, 2014: 10). She draws a parallel between the views of Aristotle and Marx on time use, referring to the 'Aristotelian-Marxist tradition'. Capitalism, by 'colonizing time' has largely denied to modern individuals the autonomy involved in the Aristotelian pursuit of the 'good life' and in the Marxian concept of the 'realm of freedom' (p. 17). While she sees women as being particularly disadvantaged by the capitalist colonization of time, her proposals include a reduction in working hours for all, as part of the 'fight for time' (Shippen, 2014: 180).

Environmentalists have also advanced the cause of reduced working hours, in this case as a means to reduce human pressures on the environment. Canadian environmentalist and political scientist Anders Hayden, in Sharing the Work: Sparing the Planet (1999), declares that, while workers have traditionally sought reduced working hours for the sake of their own dignity and health and to share the available work fairly, these motivations have now been joined by a new one: 'the increasing recognition of ecological limits' (p. 2). This calls for a reining in of the 'overconsumption' of the West by reducing either the quantity consumed (accepting 'sufficiency') or the resources required to produce a given amount of output (increasing 'efficiency') (p. 3). A programme of work-time reduction is proposed in order to find 'an alternative to the growth of production and consumption rather than to stimulate it, to create leisure as an autonomous space outside of the market rather than as a new source of market opportunities, and to start subverting the machine of capitalist consumerism rather than to simply make that machine work more equitably and smoothly' (Hayden, 1999: 188). British environmentalist Martin Pullinger (2014) proposes a voluntary 'green life course' approach to "voluntary work-time reductions ... to ... reduce environmental impacts whilst 
improving wellbeing' (p. 18). In his best-selling book, Utopia for Realists, Belgian historian Rutger Bregman (2016) argues that endless striving for economic growth in economically developed countries is causing stress for the environment, particularly in the form of global warming. He calls for a number of measures to reform to labour markets in including a 15hour work-week.

While mainstream economics provides the technical and, to a large extent, the ideological underpinning of Western economies, a number of alternative economic voices have recently called for reforms. Australian economist Tim Robinson (2006) argues that the material inputs to economic growth as currently configured are not adequately priced, which imposes unacceptable costs ('externalities') on the community and the environment. Among the measures he recommends to re-balance the economy to counter this trend is a reduction in working hours. Australian labour economist Robert LaJeunesse (2009) argues that the potential gain in social and economic benefits from work time reduction demands a range of government work-time regulation initiatives. One of the campaigns of the New Economics Foundation (NEF), a London-based think-tank, is for the introduction of a 21 hour workweek, designed to address the problems of: 'overwork, unemployment, over-consumption, high carbon emissions, low well-being, entrenched inequalities, and the lack of time to live sustainably, to care for each other, and simply to enjoy life' (New Economics Foundation, 2010: 2). The authors of How Much is Enough? are the economist Lord Robert Skidelsky, biographer of John Maynard Keynes, and his philosopher son, Edward Skidelsky, who address the age-old question of what constitutes the good life. They argue that the apparently endless pursuit of growth in the Gross Domestic Product, is morally and environmentally unsustainable. They therefore propose a range of public policy sustainability measures, including legislation to reduce weekly working hours and/or increase holidays (Skidelsky and Skidelsky, 2012: 195). American business economist Robert Grosse (2018), observing that reductions in the standard workweek from 60 hours to 40 hours were successfully implemented during the twentieth century and that there is 'nothing sacred about a 40-hour workweek' (p.108), presents a detailed case for adopting a four-day, 32-hour standard workweek.

While most critical scholars avoid reformist policy recommendations in favour of a call for fundamental change to society as a whole, a number have called for reduced working hours, or other reforms to the work-leisure relationship, as a step towards a transformed society. In a series of books published in the 1980s and 1990s, French sociologist André Gorz (1989: 166) discussed Marx's freedom/necessity distinction, but argued that, in current conditions, an autonomy/heteronomy distinction was more appropriate. He proposed that workers should seek to reduce involvement with the formal capitalist economy in favour of engagement in autonomous creative activity in the non-market sector, with reduced paid working hours as part of the process (pp. 238-9). A similar approach was later proposed by German sociologist Ulrick Beck (2000), in the form of a 'counter-model to the work society' involving a 'postnational and political civil society'. This, he declared, was based not on leisure but on political freedom in 'a multi-activity society in which housework, family work, club work and voluntary work are prized alongside paid work and returned to the centre of public and academic attention' (Beck, 2000: 125). In The Mythology of Work, British sociologist Peter Fleming (2015) offers a Marxist analysis of the phenomenon of work in contemporary capitalist society, in which he critiques the way work has come to be seen as immutable and to occupy a central position in people's lives and culture, while delivering riches to powerful élites. Among his suggestions for a 'post-labour strategy' is a three-day work week (p. 194). 
Social activist John De Graaf (2003) is the leader of the USA-based 'Take Back Your Time' movement, the mission of which is to: 'challenge the epidemic of overwork, over-scheduling and time famine ... that threatens our health, our relationships, our communities, and our environment ... and seek a renewed understanding of the value of leisure time and the costs of time stress in our lives and workplaces' (www.takebackyourtime.org). The movement campaigns for a number of benefits, including: increased holiday entitlements; paid parental leave; limitation of overtime working; and workplace flexi-time. One of the movement's initiatives is the annual 'Take Back Your Time Day' (October 24).

\section{The leisure studies response}

Leisure studies scholars have not been entirely silent on the topic of working hours, and a few exceptions should be acknowledged. Reid's (1995) call for reduced working hours in the context of a post-materialist society is discussed above. In their key text on women and leisure, Karla Henderson, Deborah Bialeschki, Susan Shaw and Valerie Freysinger (1996: 270) declare that the 'preferred future' for a reformed society would be one in which 'both females and males will have the opportunity to work a shortened workweek and will have the opportunity to pursue other alternative forms of work such as flex-time and sabbatical leave'. Hunnicutt (2013), in a follow-up to his 1980s work discussed above, argues that the 100-year long American tradition of campaigning for shorter working hours came to an end in the second half of the twentieth century due to the loss of belief in the 'Higher Progress'. This had dated from the Declaration of Independence and 'the pursuit of happiness', with economic progress being viewed as a means to an end rather than an end in itself. However, Hunnicutt concludes:

Shorter working hours remains the portal to the 'realm of freedom', offering an eminently more practical and sustainable future than the pursuit of eternal economic growth and everlasting job creation. ... Higher Progress will be possible once again when more of us choose freely to liberate more of our lives from the economy... Free people choosing more freedom is the best hope for the future. (Hunnicutt, 2013: 189-90)

In calling for social change, leisure studies scholars often face the challenge of "who is listening?' (Shaw, 2000). While some encourage communication among wider academic audiences, some look beyond to political and industrial movements. Thus Clarke and Critcher (1985) addressed their rallying call on the politics of time to the British socialist movement. The case for reform presented by Henderson et al. (1996) and by the feminists discussed in the previous section, while addressed to the community at large, can be seen as a contribution to the agenda of the feminist movement. Similarly, the environmentally-based proposals are a potential addition to the programme of an existing movement. Reid (1995) suggested that leisure industry professionals should join with like-minded groups to pursue the postmaterialist agenda. The economics-based proposals discussed above vary in the extent to which they are technical (Robinson), idealistic (Skidelsky and Skidelsky) or more politicallybase (New Economics Foundation). In the latter case, they can be seen as fostering links with the trade union movement which, while originally the champion of reduced working hours, has recently varied in the priority it has given to this demand. However, it is possible that unions might combine with other groups to prosecute the case. Cross (1989: 230) pointed out that: 'The labor movement, which formerly dominated the short-hours cause, surely cannot be expected to find solutions without the collaboration of women's and other groups', while LaJeunesse (2009: 235) sees work time reduction as 'an effective catalyst in mobilizing union members in solidarity with the unemployed, women's organizations, environmentalists, and other social reformers'. 
The call in this paper is therefore for leisure studies researchers to recognise and engage with various of these movements in relation to the cause of reduced working hours. Research on realm-of-necessity time and activity has the potential to contribute a unique perspective on the issues involved.

Kenneth Roberts has recently observed that, 'whereas work remains a huge issue and problem in society and most social sciences, the work-leisure relationship has lost its role as a stable pivot in leisure studies' (Roberts, 2018: 6). He argues that leisure studies should return to its roots and proposes a research agenda of largely empirical investigations of workers in various contemporary occupations and working conditions. The conclusion of this paper is that the realm-of-necessity/realm-of-freedom schema can provide a needed conceptual framework for such research. The primary research task would be to investigate the nature and required extent of realm-of-necessity activity in contemporary conditions - something which might be seen as a human right (Rose, 2016; Veal, 2015). This covers not only paid work, but also unpaid domestic work and care activity, recuperative leisure and activity for the maintenance of family and social relationships. These are all 'realm of necessity' activities which tend to feature in contemporary discussions of 'time-squeeze'. Only when such research has been addressed will the field be in a position to move on to address the issue of realm-of-freedom time and activity.

\section{References}

Aitchison, C. (2010). Labouring the leisure society thesis: a commentary on Rojek's 'Leisure and emotional intelligence'. World Leisure Journal, 52(4), 265-69.

Anderson, N. (1967). Work and leisure. London: Routledge and Kegan Paul.

Andrew, E. (1981). Closing the iron cage: The scientific management of work and leisure. Montreal: Black Rose Books.

Basso, P. (1998/2003) Modern Times, Ancient Hours: Working lives in the twenty-first century. London: Verso (Originally published in Italian by Franco Angeli, Milan, 1998).

Baudrillard, J. (1970/1998). The drama of leisure or the impossibility of wasting one's time. In The consumer society: Myths and structures (pp. 151-8). London: Sage.

Beck, U. (2000). The brave new world of work. Cambridge: Polity.

Berger, B.M. (1962). The sociology of leisure: Some suggestions. In E.O. Smigel, (Ed.), Work and leisure (pp. 21-40). New Haven, CN: College and University Press.

Bramham, P. (2006). Hard and disappearing work: making sense of the leisure project. Leisure Studies, 25(4), 379-90.

Bregman, R. (2016). Utopia for realists: The case for a universal basic income, open borders, and a 15-hour work-week. Amsterdam: The Correspondent.

Caldwell, J.A., Caldwell, L., Thompson, L.A., and Lieberman, H.R. (2019). Fatigue and its management in the workplace. Neuroscience and Biobehavioral Reviews, 96, 272-89.

Chapman, S.J. (1909). Hours of work. Economic Journal, 19(75), 353-73.

Clarke, J., and Critcher, C. (1985). The Devil makes work: leisure in capitalist Britain. Basingstoke, UK: Macmillan.

Cross, G. (1989). A quest for time: The reduction of work in Britain and France, 1840-1940. Berkeley, CA: University of California Press.

Currell, S. (2005). The march of spare time: The problem and promise of leisure in the Great Depression. Philadelphia, PA: University of Pennsylvania Press.

Dare, B., Walton, G., and Coe, W. (1998). Concepts of leisure in Western thought. Dubuque, IA; Kendal/Hunt. 
De Graaf, J. (Ed.) (2003). Take back your time: Fighting overwork and time poverty in America. San Francisco, CA: Berrett-Koehler.

Deem, R. (1986). All work and no play? The sociology of women and leisure. Milton Keynes, UK: Open University Press.

Dembe, A.E. (2009). Ethical issues relating to the health effects of long working hours. Journal of Business Ethics, 84, 195-208.

Dubin, R. (1963). Industrial workers' worlds: A study of the 'central life interest' of industrial workers. In E.O. Smigel (Ed.), Work and Leisure (pp. 53-72.). New Haven, $\mathrm{CN}$ : College and University Press.

Dumazedier, J. (1962/1967). Toward a society of leisure. New York: Free Press (Original French edition: Editions du Seuil, Paris, 1962).

Dumazedier, J. (1971). Leisure and post-industrial societies. In M. Kaplan and P. Bosserman (Eds), Technology, human values, and leisure (pp. 191-220). Nashville, TN: Abingdon Press.

Dumazedier, J. (1974). Sociology of leisure. Amsterdam: Elsevier.

Dumazedier, J. (1989). France: leisure sociology in the 1980s. In A. Olszewska and K. Roberts (Eds), Leisure and lifestyle: A comparative analysis of free time (pp. 143-6). London: Sage.

Fleming, P. (2015). The mythology of work: Why capitalism persists despite itself. London: Pluto.

Friedman, G. (1945/1955). Industrial society: The emergence of the human problems of automation. Glencoe, IL: Free Press (Original published in French in 1945).

Friedmann, G. (1956/1961). The anatomy of work: Labor, leisure, and the implications of automation. Glencoe, IL: Free Press (Original French edition: Le Travaille en Miettes: spécialisations et loisir. Paris: Gallimard, 1956).

Gans, H. (1968). Outdoor recreation and mental health. Chapter 9 of, People and plans (pp. 108-25). New York: Basic Books.

Goldthorpe, J.H., Lockwood, D., Bechhofer, F., and Platt, J. (1969). The affluent worker in the class structure. Cambridge: Cambridge University Press.

Gorz, A., (1989). Critique of economic reason. London: Verso.

Green, E., Hebron, S., \& Woodward, D. (1990).Women's leisure, what leisure? Basingstoke, UK: Macmillan.

Grosse, R. (2018). The four-day workweek. London: Routledge.

Hayden, A. (1999). Sharing the work, sparing the planet: Work time, consumption and ecology. Toronto, Canada: Between the Lines.

Henderson, K., Bialeschki, M.D., Shaw, S.M., and Freysinger, V.J. (1996). Both gains and gaps: Feminist perspectives on women's leisure. State College, PA: Venture.

Hochschild, A.R. (1989). The second shift. New York: Avon Books.

Hochschild, A.R. (1997). The time bind: When work becomes home and home becomes work. New York: Metropolitan Books.

Hunnicutt, B.K. (1980). Historical attitudes toward the increase of free time in the twentieth century: time for work, for leisure, or as unemployment. Society and Leisure, 3(2), 195215.

Hunnicutt, B.K. (1988). Work without end: Abandoning shorter hours for the right to work. Philadelphia, PA: Temple University Press.

Hunnicutt, B.K. (2013). Free time: The forgotten American dream. Philadelphia, PA: Temple University Press.

Kabanoff, B. (1980). Work and nonwork: A review of models, methods and findings. Psychological Bulletin, 88(1), 60-77. 
Kandiyali, J. (2014). Freedom and necessity in Marx's account of communism. British Journal for the History of Philosophy, 22(1), 104-23.

Kaplan, M. (1960). Leisure in America: A social inquiry. New York: John Wiley.

Kelly, J.R. (1972). Work and leisure: A simplified paradigm. Journal of Leisure Research, 4(1), 50-62.

Kelly, J.R. (1978). A revised paradigm of leisure choices. Leisure Sciences, 1(4), 345-63.

LaJeunesse, R.M. (2009). Work time regulation as sustainable full employment strategy: The social effort bargain. London: Routledge.

Lenneis, V., and Pfister, G. (2017). Too tired for exercise? The work and leisure of female cleaners in Denmark, Leisure Studies, 36(4), 530-41.

Marcuse, H. (1962). Preface to the Vintage edition. In Eros and civilization (pp. vii-xi). New York: Vintage Books.

Marcuse, H. (1964). One dimensional man. London: Routledge \& Kegan Paul.

Marx, K. (1867/1957). Capital, Vol. I. London: Dent.

Marx, K. (1894/1974). Capital, Vol. III. London: Lawrence and Wishart.

McIntosh, S. (1981) Leisure studies and women. In A. Tomlinson (Ed.), Leisure and Social Control (pp. 93-112). London: Leisure Studies Association.

Molitor, G.T.T. (2000). The dawn of the leisure era. Association Management, 60(2), 76-83.

Mommaas, H. (1997). European leisure studies at the crossroads? A history of leisure research in Europe. Leisure Sciences, 19(4), 241-54.

Moorehouse, H.F. (1989). Models of work, models of leisure. In C. Rojek (Ed.), Leisure for leisure (pp. 15-35). Basingstoke, UK: Macmillan.

Nash, J.B. (1932). Spectatoritis: Re-creation not wreck-creation. New York: Holston House/Sears Publishing.

Nash, J.B. (1953/1960). Philosophy of recreation and leisure. Dubuque, IA: Wm. C. Brown.

Near, J.P., Rice, R.W., and Hunt, R.G. (1980). The relationship between work and nonwork domains: A review of empirical research. Academy of Management Review, $5(3), 415-29$.

Negrey, C.L. (2012). Work time: Conflict, control, and change. Cambridge, UK: Polity.

Neulinger, J. (1974). The psychology of leisure. Springfield, IL: Charles C. Thomas.

Neulinger, J. (1981). To leisure: An introduction. Boston, MA: Allyn and Bacon.

Neumeyer, M.H., and Neumeyer, E.S. (1936). Leisure and recreation: A study of leisure and recreation in their sociological aspects. New York: A.S. Barnes.

Neumeyer, M.H., and Neumeyer, E.S. (1949). Leisure and recreation: A study of leisure and recreation in their sociological aspects, Revised edn. New York: A.S. Barnes.

New Economics Foundation (2010). 21 hours: Why a shorter working week can help us all to flourish in the $21^{\text {st }}$ century. London: NEF.

Orzack, L.H. (1963). Work as a 'central life interest' of professionals. In E.O. Smigel, (Ed.), Work and leisure (pp. 73-84). New Haven, CN: College and University Press.

Parker, S. (1965). Work and non-work in three occupations. Sociological Review, 13(1), 6575.

Parker, S. (1971). The future of work and leisure. London: McGibbin \& Kee.

Parker, S. (1983). Leisure and work. London: George Allen and Unwin.

Pullinger, M. (2014). Working time reduction policy in a sustainable economy: Criteria and options for its design. Ecological Economics, 103, 11-19.

Reid, D.G. (1995). Work and Leisure in the 21st Century: From production to citizenship. Toronto, Canada: Wall and Emerson.

Riesman, D. (1954). Some observations on changes in leisure attitudes. In Individualism reconsidered: Selected essays (pp. 126-47). Garden City, NY: Doubleday Anchor Books. 
Riesman, D. (1964). Some issues in the future of leisure. In Abundance for what? And other essays (pp. 184-95). Garden City, NY: Doubleday.

Roberts, K. (1970). Leisure. London: Longman.

Roberts, K. (1978). Contemporary society and the growth of leisure. London: Longman.

Roberts, K. (1999). Leisure in contemporary society. Wallingford, UK: CABI Publishing.

Roberts, K. (2007). Work-life balance - the sources of the contemporary problem and the probable outcomes: A review and interpretation of the evidence. Employee Relations, 29(4), 334-51.

Roberts, K. (2016). Social theory, sport and leisure. London: Routledge.

Roberts, K. (2018). A future for UK leisure studies: back to work. International Journal of the Sociology of Leisure. Online: doi: 10.1007/s41978-018-0029-z.

Robinson, J.P., and Godbey, G. (1997). Time for life: The surprising ways Americans use their time. University Park, PA: Pennsylvania State University Press.

Robinson, T. (2006). Work, leisure and the environment: The vicious circle of overwork and over-consumption. Cheltenham, UK: Edward Elgar.

Rojek, C. (1984). Did Marx have a theory of leisure? Leisure Studies, 3(2), 163-74.

Rojek, C. (1985). Capitalism and leisure theory. London: Tavistock.

Rojek, C. (2013). Is Marx still relevant to the study of leisure? Leisure Studies, 32(1), 19-33.

Rose, J.L. (2016). Free time. Princeton, NJ: Princeton University Press.

Rosenzweig, R. (1983). Eight hours for what we will: Workers and leisure in an industrial city, 1870-1920. Cambridge, UK: Cambridge University Press.

Schor, J. (1991). The overworked American: The unexpected decline of leisure. New York: Basic Books.

Schulte, B. (2014). Overwhelmed: How to work, love, and play when no one has the time. New York: Picador.

Shaw, S. (2000). If our research is relevant, why is nobody listening? Journal of Leisure Research, 32(1), 147-51.

Shippen, N.M. (2014). Decolonizing time: Work, leisure and freedom. Basingstoke, UK: Palgrave Macmillan.

Skidelsky, R., \& Skidelsky, E. (2012). How much is enough? The love of money and the case for the good life. London: Allen Lane.

Smigel, E.O. (Ed.) (1963). Work and leisure. New Haven, CN: College and University Press.

Staines, G.L. (1980). Spillover versus compensation: A review of the literature on the relationship between work and non-work. Human Relations, 33(2), 111-29.

Van Moorst, H. (1982). Leisure and social theory. Leisure Studies, 1(2),157-170.

Veal, A.J. (2011). The leisure society I: Myths and misperceptions, 1960-79. World Leisure Journal, 53(3), 206-27.

Veal, A.J. (2013). Lifestyle and leisure theory. In T. Blackshaw (Ed.), Routledge handbook of leisure studies (pp. 266-79). London: Routledge.

Veal, A.J. (2015). Human rights, leisure and leisure studies. World Leisure Journal, 57(4), 249-72.

Veal, A.J. (2019a). Whatever happened to the leisure society? London: Routledge.

Veal, A.J. (2019b). Joffre Dumazedier and the definition of leisure. Loisir et Société/Society and Leisure, DOI: 10.1080/07053436.2019.1625533.

Weeks, K. (2011). The problem with work: Feminism, Marxism, anti-work politics, and postwork imaginaries. Durham, NC: Duke University Press.

Zuzanek, J. (2009). Time use research in Canada: History, critique, perspectives. International Journal of Time Use Research, 6(2), 178-92. 


\footnotetext{
i There is some debate in the literature over apparent inconsistencies concerning the relationship between work, freedom and the 'realm of necessity' in Marx's writings (e.g., see Rojek, 1985: 35-6; Kandiyali, 2014).

'Necessity' in this paper refers to the idea that provision to meet basic needs is the prime economic consideration in 'all social formations and under all possible modes of production' (Marx, 1894/1974: 820). The issue of 'surplus labour'/profit in the system is not considered here. Although numerous leisure scholars have examined the relevance of Marxian ideas to leisure studies (e.g., Dare, Walton and Coe, 1998: 177-95; Roberts, 2016: 56-60; Rojek, 1984, 2013), none has explored realm-of-necessity/realm-of-freedom activities in the detail offered in this paper.

ii It should also be noted that 'freedom' here is not used in the sense of 'perceived freedom' as in some definitions of leisure (e.g., Neulinger, 1974: 15). Therefore people may or may not experience a subjective sense of freedom when engaged in realm-of-necessity leisure activity.

iii For a more extensive review see Veal (2019a: chapters 4-8).

iv In his 1974 book Dumazedier (1974: 18, 67) renounced his functional definition of leisure it in favour of one aligned with the Leisure Aristotelian view (Van Moorst, 1982), with leisure reserved exclusively for personal development activity - function (3) in his original definition (Veal, 2019b).

${ }^{v}$ It has not been possible to locate this observation in Parker (1971). In Parker (1983: 121) there is discussion of the tendency for harmful work to be less common.
} 